
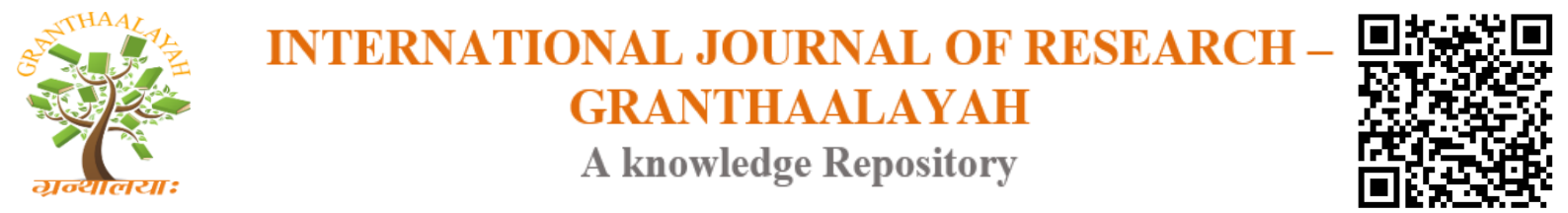

Management

\title{
CONSUMER'S PERCEPTION TOWARDS NEUROMARKETING IN INDIA WITH SPECIAL REFERENCE TO KANO MODEL
}

\author{
Harit Kumar $^{* 1}$, Dr. Neha Mathur², Dr. Sangeeta Jauhari ${ }^{3}$ \\ ${ }^{* 1}$ Research Scholar, AISECT University, Bhopal, India \\ ${ }^{2}$ Dean, Department of Management, AISECT University, Bhopal, India \\ ${ }^{3} \mathrm{HOD}$, Department of Management, AISECT University, Bhopal, India
}

DOI: https://doi.org/10.29121/granthaalayah.v5.i4.2017.1803

\begin{abstract}
This paper presents how consumer's perception towards neuromarketing can be analyzed by using Kano model and discusses the potential benefits that can be achieved by applying this approach to skis the application of neuromarketing. Neuromarketing investigates important information that commonly consumer purchase decisions take place at a mental, emotional and instinctive level; those take place in the subconscious brain that is under the levels of controlled awareness. Due to this striking motive, the perception technologists of the market are extremely keen to study the techniques of successful handling of the subconscious brain actions. The major reason is to encourage the preferred response in person's perception as intensely as possible. This article with the application of Kano Model examines the impact of application of neuroscience techniques on marketing practices as these communicate to the exercise of individual free will. This study centers to investigate the consumer's perception towards neuromarketing by Kano questionnaire; includes questions involving consumers' awareness, consent, and understanding to what may be viewed as foray of their privacy rights.
\end{abstract}

Keywords: Consumer Perception; Kano's Model; Kano's Questionnaire; Neuroscience; Neuromarketing.

Cite This Article: Harit Kumar, Dr. Neha Mathur, and Dr. Sangeeta Jauhari. (2017). "CONSUMER'S PERCEPTION TOWARDS NEUROMARKETING IN INDIA WITH SPECIAL REFERENCE TO KANO MODEL." International Journal of Research - Granthaalayah, 5(4), 135-142. https://doi.org/10.29121/granthaalayah.v5.i4.2017.1803.

\section{Introduction}

The emerging application of neuroscience techniques in marketing by the name of neuromarketing, which conduct customer brain research in a managerial decision making, it has been observed that neuromarketing is gaining popularity in the academics and business world as well. Therefore, the aim of this paper is to measure the consumer perception towards 
neuromarketing tools. Although, available neuromarketing studies do not provide clear impression of neuromarketing influence on consumer perception while considering technical as well as ethical issues. The article uses the approach of Kano Model in order to do so.

As neuromarketing was emerged in 2002, its application is continuously increasing and it is becoming famous among companies, marketers and advertisers (Morin, 2011). Although the term neuromarketing has connected with medical industry and psychology, this paper will focus on the consumer perception towards neuromarketing in India particularly.

In current scenario, all the markets are congested by plentiful similar and yet a little different products, Neuromarketing emerged as a key discipline to regularly innovate and distinguish products, which meet customer needs positively (Leonard, \& Rayport, 1997; Dapkevičius, \& Melnikas, 2011). By reason of marketer first intention of meeting customer needs, there is a need to evaluate customer brain, involved in purchase decision making and this objective is performed by neuromarketing research techniques (Kenning \& Plassmann, 2008; Huettel et al., 2009b). Consequently, neuromarketing techniques such as eye tracking, skin conductance, fMRI, EEG etc. are commonly getting increased concentration and provide better understanding about consumer's brain inside to marketers (Lieberman, 2007; Dimoka, Banker, Benbasat, Davis, Dennis, Gefen, \& Weber, 2012; Calvert, \& Brammer, 2012; Ariely \& Berns, 2010; Venkatraman et al., 2012).

This paper will measure consumer perception towards neuromarketing in India with the help of Kano's model i.e, is based on the two-factor theory Herzberg and gave a helpful diagram to identify ranking of customer's satisfaction or dissatisfaction of a particular product or service (Tan and Shen, 2000; Kuo, 2004; Tontini, 2007). In fact, an offering of a marketer, a customer might have a variety of satisfaction or dissatisfaction on the basis their needs are fulfilled completely, met partially, or unserved (Martensen and Gronholdt, 2001). Kano proposes a dimension that goes from total satisfaction (also called Delight and Excitement) to total dissatisfaction (or Frustration).

Japanese researcher and consultant Noriaki Kano published a paper in 1984. This paper described about procedure that gives contribution in measuring customer's satisfaction towards product. Outcome of that research is commonly called as Kano Model. One can conclude about how customer's feelings through a questionnaire, and that questionnaire is known as Kano questionnaire.

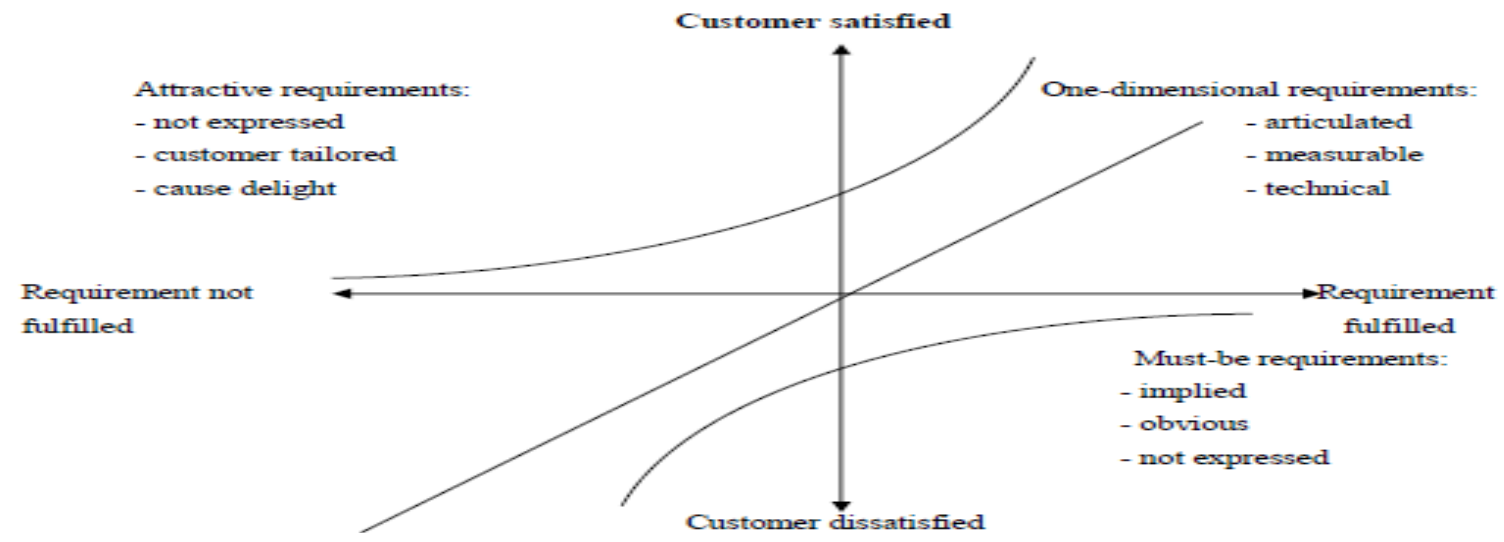

Figure 1: Kano model of customer satisfaction (Sauerwein et al., 1996) 


\section{Literature Review}

Now days marketers have adopted an integrative field as neuromarketing, that have been emerged for better understanding and characterizing the neural correlation behind consumer behavior and the processes underlying choice. These human behavioral theories have started to integrate conclusion from neuroscience to discriminate the neurological and physiological basics as well as the somatic factors that control consumer behavior. As such, neuromarketing evolved from the integration of marketing and neuroscience and projected an interdisciplinary approach to probing the neural correlates of consumer decision-making (Sanfey, Lowenstein, McClure \& Cohen, 2006).

Neuromarketing is a discipline within neuroeconomics that look into marketing related decisionmaking and leverages insights arising from consumer's neurological data (Fugate, 2007).

Neuromarketing focuses to examine consumer behavior through the application of neural processes and neuroscientific techniques sequentially to form a holistic concept of the neural basis of brand relationships and purchasing power. This emerging field has its scope to scientifically explain psychological position of customer that play a significant role in consumer buying decision and to provide a broad estimation of the effectiveness and influence of a range of marketing tactics for example advertising and product placement through focusing on how these tactics change an individual's neurobiology. Neuromarketing provides platform for investigation into the neural pathways and processes that pave consumer purchasing behaviors through neuroimaging and event-related potentials (ERP) (Javorm Koller, Lee, Chamberlain \& Ransmayr, 2009).

Neuromarketing, as a discipline of marketing commercially introduced in 2002 by companies such as SalesBrain and Brighthouse. These companies started offering marketing and consulting services that were based in neuroscience techniques (Morin, 2013). In the first neuromarketing study, McClure used fMRI data to find the neural correlates of participant's preferences between Coke and Pepsi (Morin, 2013).

It has been observed by Morin in 2011 that neuromarketing has potential to investigate 4P's of marketing- product, price, promotion and place- and can contribute extensively to marketer's understanding about effectively marketing their products or services. An increasing number of marketing research papers, journals, schools, organizations and conferences utilize neuroscientific data to better understanding behind consumer buying decision-making and the ways by which that knowledge can be utilized to develop innovative marketing practices. Neuromarketing has offered lots of opportunities for companies to constantly determine implicit reactions to marketing stimuli, the field is still at an emerging stage.(Morin, 2011).

Martin Lindstorm's in his book "Buyology - Truth and Lies about Why We Buy" (2010) proposes that subconscious mind plays a key role in consumer's buying decisions. Neuromarketing is a field of marketing research, oriented towards Branding, Product design, Advertising, Customer decision making etc. 
Neuromarketing applies various techniques for measuring consumer behavior including Eye tracking (measuring eye gaze patterns, say, on a landing page), Analysing facial expressions, Behavioural experiments, Biometrics (body signal measures) that measure perspiration, respiration, heart rate, and facial muscle movement (electromyography [EMG]) and Neuromeric (brain signal measures) that measure electrical activity (electroencephalography [EEG]), and blood flow (functional magnetic resonance imaging [fMRI]) in the brain.

The Kano model focuses different product attributes. Traditionally for measuring customer satisfaction the relationship between the attributes and customer satisfaction was linearly observed. Kano model more specifically classifies the customer satisfaction between the performance of attributes and customer satisfaction as non-linear. It takes attributes as "mustbe", "one-dimensional" or "attractive" (Kano et al., 1984, Berger et al. 1993, Matzler et al. 1996, Nilson-Witell and Fundin 2005).

In 1984, Kano proposed the conceptual explanation of the Kano methodology, with the application of Kano questionnaire, a new research field was born and with this concept Kano presented his theory of "attractive quality and must-be quality" in the Western world. (Kano 1995, Yamada, 1998). Witell et. al., (2013) advised to use the traditional five-level Kano questionnaire.

To better understand the customer perception about an offering, group of functional and dysfunctional questionnaire design is applied. It aims to find out the customer perception towards offering of marketers (Lee et al., 2009).

A review of various researches proves the application of Kano's Model useful in measuring the Consumer perception. Kano's Model has been applied extensively within scholarly research (e.g., Bhattacharyya \& Rahman, 2004; Emery \& Tian, 2002; Emery \& Tolbert, 2003; Liu,2008; Liu \& Wu,2009; Schvaneveldt, Enhawa \& Miyakawa, 1991; Fuller \& Matzler, 2007; Schvaneveldt, Matzler \& Hinterhuber, 1998; Yang, 2003 \& 2005) and within a variety of contexts such as manufactured consumer products (Miyakawa \& Wong, 1989), consumer services including banking, cleaning services, restaurants, and grocery stores (Schvaneveldt, 1991), website design, (Von Dran, Zhang \& Small,1999), the retail ski product industry (Matzler \& Hinterhuber, 1998), transportation (Silvestro \& Johnson, 1990), as well as studies in employee satisfaction (Matzler, 2004) and student/professor satisfaction (Emery, 2006).

\section{Objectives of Research}

- To identify consumer's perception on market research studies for knowing their needs towards product attributes.

- To ascertain consumer's perception on emerging integration of neuromarketing techniques in market research studies.

\section{Methodology}

This research measures consumer's perception towards neuromarketing in India through the implementation of a quantitative survey administered on emerging integration of neuromarketing 
techniques in market research studies in India. The survey instrument is based on the Kano Model questionnaire format.. Participants in the study are qualified to participate as they are Academicians and 100 respondents were selected through random sampling from management colleges of U.P and M.P. in India.

\subsection{Kano Questionnaire}

In order to uncover our customer's perceptions towards neuromarketing, this research uses the Kano questionnaire. It consists of a pair of questions for each feature researcher wants to evaluate:

1(A) Neuromarketing is an emerging branch of neuroscience where with the application of Biological techniques researchers can better understand the Buy-ology of customer, how do you feel?

- I like it that way.

$\square$ It must be that way.

$\square$ I am neutral.

$\square$ I can live with it that way.

$\square$ I dislike it that way.

1 (B) Neuromarketing is an emerging branch of neuroscience where with the application of Biological techniques researchers cannot better understand the Buy-ology of customer, how do you feel?

$\square$ I like it that way.

$\square$ It must be that way.

- I am neutral.

$\square$ I can live with it that way.

$\square$ I dislike it that way.

The first question is called the functional form and the second one is the dysfunctional form.

Researcher will do this through an evaluation table that combines the functional and dysfunctional answers in its rows and columns (respectively,). Each answer pair leads to one of those categories.

\begin{tabular}{|c|c|c|c|c|c|c|}
\hline \multicolumn{2}{|c|}{ Customer requirements } & \multicolumn{5}{|c|}{ Dysfunctional (negative) question } \\
\hline & & Like & Must-be & Neutral & Live with & Dislike \\
\hline \multirow{5}{*}{$\begin{array}{l}\text { Functional } \\
\text { (positive) } \\
\text { question }\end{array}$} & \multirow{5}{*}{$\begin{array}{l}\text { Like } \\
\text { Must-be } \\
\text { Neutral } \\
\text { Live with } \\
\text { Dislike }\end{array}$} & $\mathrm{Q}$ & A & A & A & $\mathrm{O}$ \\
\hline & & $\mathrm{R}$ & I & I & I & M \\
\hline & & $\mathrm{R}$ & I & I & I & $\mathrm{M}$ \\
\hline & & $\mathrm{R}$ & I & I & I & M \\
\hline & & $\mathrm{R}$ & $\mathrm{R}$ & $\mathrm{R}$ & $\mathrm{R}$ & Q \\
\hline \multicolumn{4}{|c|}{ A: Attractive } & \multicolumn{3}{|c|}{ O: One-dimensional } \\
\hline \multicolumn{2}{|c|}{ M: Must-be } & \multicolumn{5}{|c|}{ Q: Questionable } \\
\hline \multicolumn{2}{|c|}{ R: Reverse } & \multicolumn{5}{|c|}{ I: Indifferent } \\
\hline
\end{tabular}

Figure 2: Kano Questionnaire Evaluation (Sauerwein et al., 1996) 


\subsection{Analysis and Interpretation}

The questionnaire is analysed in three steps. After combined functional (positive) and dysfunctional (negative) question's answers (see Figure 2), the next step is the results analysis and interpretation. Below Table 1 is presented and it shows Consumer's Perception towards neuromarketing in India. The easiest way for the results interpretation is analysis, which is based on the response rate of recurrence.

Table 1: Consumer Perception towards Neuromarketing (Kano Questionnaire Evaluation)

\begin{tabular}{|l|l|l|l|l|l|l|l|l|}
\hline Factors (Customer Requirements) & A & $\mathbf{O}$ & $\mathbf{M}$ & $\mathbf{I}$ & $\mathbf{R}$ & $\mathbf{Q}$ & Total & Category \\
\hline Need of Market Research & 32 & 41 & 1 & 21 & 2 & 3 & 100 & O \\
\hline Buy-Ology of Customer & 42 & 16 & 3 & 35 & & 4 & 100 & A \\
\hline $\begin{array}{l}\text { Application of Neuroscientific Techniques In } \\
\text { Market Research }\end{array}$ & 17 & 5 & 2 & 58 & 15 & 3 & 100 & I \\
\hline Study of Customer's Subconscious Mind & 17 & 14 & 2 & 61 & 2 & 4 & 100 & I \\
\hline Need of Application of Neuromarketing In India & 14 & 35 & 3 & 32 & 14 & 2 & 100 & O \\
\hline $\begin{array}{l}\text { Influence of Neuromarketing On Customer } \\
\text { Purchase Decisions }\end{array}$ & 35 & 31 & 2 & 18 & 12 & 3 & 100 & A \\
\hline $\begin{array}{l}\text { Efficacy of Marketing Activities With } \\
\text { Neuromarketing }\end{array}$ & 61 & 13 & 3 & 20 & 2 & 1 & 100 & A \\
\hline Neuromarketing; On The Basis Of Ethicality & 8 & 7 & 3 & 10 & 60 & 12 & 100 & R \\
\hline $\begin{array}{l}\text { Consumer Dissonance On Revealed Usage of } \\
\text { Neuromarketing }\end{array}$ & 12 & 5 & 13 & 56 & 8 & 6 & 100 & I \\
\hline
\end{tabular}

The Kano's categories of nine items in this study:

Table 2: Categories of consumer perception towards neuromarketing in India

\begin{tabular}{|l|l|}
\hline Attractive & $\begin{array}{l}\text { Buy-ology of Customer } \\
\text { Influence of Neuromarketing On Customer Purchase Decisions } \\
\text { Efficacy of Marketing Activities With Neuromarketing }\end{array}$ \\
\hline One-dimensional quality & $\begin{array}{l}\text { Need of Market Research } \\
\text { Need of Application of Neuromarketing In India }\end{array}$ \\
\hline Indifferent & $\begin{array}{l}\text { Application of Neuroscientific Techniques In Market Research } \\
\text { Study of Customer's Subconscious Mind } \\
\text { Consumer Dissonance On Revealed Usage Of Neuromarketing }\end{array}$ \\
\hline Reverse & Neuromarketing; On The Basis Of Ethicality \\
\hline
\end{tabular}

\section{Conclusions}

This study proposes an integrated approach of Consumer Perception Analysis with Kano's model questionnaire for identifying Indian consumer perception and this study concludes that in India. 
Consumers have positive perceptions towards market research and application of neuromarketing in conducting market research. As per the perception of Indian consumers neuromarketing plays a vital role in terms of understanding Buy-ology of Customer, Customer Purchase Decisions and contribute in building the efficacy of Marketing Activities. On the other side they have indifferent perception towards application of neuroscientific techniques for the study of their unconscious min. And at last Indian consumers have a clear perception that application of neuromarketing without revealing is totally unethical and it creates consumer dissonance.

\section{References}

[1] Ariely, D., \& Berns, G. S. Neuromarketing: the hope and hype of neuroimagingin business. Nature Reviews Neuroscience, 2010, 11(4), 284-292.

[2] Bhattacharyya, S., \& Rahman, Z. Capturing the customer's voice, the centerpiece of strategy making: A case study in banking. European Business Review, 2004, 16(2), 128-138.

[3] Berger, C., Blauth, R., Boger, D., Bolster, C., Burchill, G., DuMouchel, W., Pouliot, F., Richter, R., Rubinoff, A., Shen, D., Timko, M. and Walden, D. Kano's methods for understanding customer-defined quality. The Center for Quality of Management Journal, 1993, 2(4), 2-36.

[4] Dapkevičius, A., \& Melnikas, B Influence of price and quality to customer satisfaction: neuromarketing approach. Science-Future of Lithuania/Mokslas-Lietuvos Ateitis, 2011, 1(3), 1720

[5] Dimoka, A., Banker, R. D., Benbasat, I., Davis, F. D., Dennis, A. R., Gefen, D., \& Weber, B. On the use of neurophysiological tools in IS research: developing a research agenda for neurois. MIS Quarterly, 2012, 36(3).

[6] Emery, C. An examination of professor expectations based on the Kano model of customer satisfaction. Academy of Educational Leadership Journal, 2006, 10(1), 11.

[7] Emery \& Tolbert, S. Using the Kano model of customer satisfaction to define and communicate supervisor expectations. Allied Academies International Conference (2003).

[8] Emery \& Tian, R. Schoolwork as products, professors as customers: A practical teaching approach in business education. Journal of Education for Business, 2002,78(2), 97-102

[9] Fugate D.L. Neuromarketing: a layman's look at neuroscience and its potential application to marketing practice. Journal of Consumer Mar- keting 2007, 24(7): 385-394.

[10] Fuller, J., \& Matzler, K. Virtual product experience and customer participation - A chance for customer-centered, really new products. Technovation, 2007, 27(6), 378-387.

[11] Huettel SA, Song AW, McCarthy G, Functional magnetic resonance imaging, 2009, 2nd edn. Sinauer, Sunderland

[12] Kano, N. Upsizing the organization by attractive quality creation. In Total Quality Management 1995, pp. 60-72, Springer Netherlands

[13] Kenning, P., \& Plassmann, H. NeuroEconomics: An overview from an economic perspective. Brain Research Bulletin, 2005, 67(5), 343-354.

[14] Kuo Y-F, Integrating Kano's model into web-community service quality. Total Qual. Manage., 2004, 15(7): 925 - 939.

[15] Lee YC, Huang SY A new fuzzy concept approach for Kano’s model. Expert Syst. Appl. 2009, 36:4479-4484.

[16] Leonard, D., \& Rayport, J. F., Spark innovation through empathic design. Harvard business review, 1997, 75, 102-115.

[17] Lieberman, M. D., Social Cognitive Neuroscience: A Review of Core Processes, Annual Review of Psychology 2007, (58), pp. 259-289.

[18] Lindstrom, M., Buyology: Truth and lies about why we buy. Random House Digital, Inc. 2010. 
[19] Liu \& Wu, S., Service quality of student dorms using a refined Kano 2D model: A case study of a national hospitality college in southern Taiwan. Journal of Information \& Optimization Sciences, 2009, 30(3), 481-488.

[20] Liu, M., Using the refined Kano's model to measure university education quality: The case study on the department of food and beverage management in southern Taiwan. Business Review, Cambridge, 2008, 11(1), 111-117.

[21] Matzler, K., Fuchs, M., \& Schubert, A., Employee satisfaction: Does Kano's model apply? Total Quality Management \& Business Excellence, 2004, 15(9-10), 1179-1198.

[22] Matzler, K., Hinterhuber, H. H., Bailom, F., \& Sauerwein, E., How to delight your customers. Journal of Product \& Brand Management, 1996, 5(2), 6-18.

[23] Matzler \& Hinterhuber, H. How to make product development projects more successful by integrating Kano's model of customer satisfaction into quality function deployment. Technovation, 1998, 18(1), 25-38.

[24] Miyakawa, M., \& Wong, C, Analysis of attractive quality and must-be quality through product expectation factors. Proceedings of 35th Technical Conference, Tokyo. Society for Quality Control, 1989, 101-104.

[25] Morin, C., Neuromarketing: the new science of consumer behavior. Society, 2011, 48(2), 131135.

[26] Nilsson-Witell, L., \& Fundin, A., Dynamics of service attributes: a test of Kano's theory of attractive quality. International Journal of Service Industry Management, 2005, 16(2), 152-168.

[27] Sanfey, A. G., Loewenstein, G., McClure, S. M., \& Cohen, J. D., Neuroeconomics: cross-currents in research on decision-making. Trends in cognitive sciences, 2006, 10(3), 108-116.

[28] Sauerwein E., Bailom F., Matzler K., Hinterburger H., The Kano Model: How to delight your customers. Available at:http://faculty.kfupm.edu.sa/CEM/bushait/CEM_1996, 515082/kano/kano-model2.pdf.

[29] Tan KC, Shen XX , Integrating Kano's model in the planning matrix of quality function deployment. Total Qual. Manage., 2000, 11(8): 1141 - 1151.

[30] Tontini G, Integrating the Kano model and QFD for designing new products. Total Qual. Manage. Bus. Excell., 2007, 18(6): 599 - 612.

[31] Venkatraman, V., Clithero, J. A., Fitzsimons, G. J., \& Huettel, S. A., New scanner data for brand marketers: How neuroscience can help better understand differences in brand preferences. Journal of Consumer Psychology, 2012, 22(1), 143-153.

[32] Von Dran, G., Zhang, P., \& Small, R, Quality Websites: An Application of the Kano Model to Website Design, AMCIS 1999 Proceedings. 1999, Paper 314. Retrieved from http://aisel.aisnet.org/amcis1999/314

[33] Yang, C., Establishment and applications of the integrated model of service quality measurement. Managing Service Quality, 2003, 13(4), 310-324.

[34] Yang, C., The refined Kano's model and its application. Total Quality Management \& Business Excellence, 2005, 16(10), 1127-1137.

[35] Yamada, S. Idea generation in attractive quality creation. In Proceedings of the Second International Congress on Total Quality Management, Belgrade 1998, (pp. 542-7).

\footnotetext{
*Corresponding author.

E-mail address: harit.hradesh@gmail.com
} 